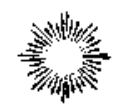

CHAPTER EIGHT

\section{Collective Bargaining in American Higher Education}

Ronald G. Ehrenberg, Daniel B. Klaff, Adam T. Kezsbom, and Matthew P. Nagowski

$\mathrm{N}$ o discussion of governance in higher education would be complete without a consideration of the role of collective bargaining. Historically, most researchers interested in the subject have directed their attention to the unionization of faculty members. Given several recent decisions by the National Labor Relations Board (NLRB) that leave open the possibility that unionization of faculty in private colleges and universities may increase in the future, we discuss collective bargaining for faculty in the first section (Leatherman 2000, AI6).

Recently, however, attention has been also directed at the unionization of two other groups in the higher education workforce. Activists on a number of campuses have pressed for academic institutions to pay their low-wage employees a living wage, and this has brought attention to the role of staff collective bargaining in academia. In the second section, we present the first empirical estimates of the impact of staff bargaining on staff salaries in higher education.

Finally, the number of public universities in which teaching assistants, and in some cases research assistants, have won the right to bargain collectively began to expand rapidly at the turn of the twenty-first century.

We are grateful to the Andrew W. Mellon Foundation and the Adantic Philanthropies (Inc.) USA for their support of the Cornell Higher Education Research Institute. Without implicating them for what remains, we are grateful to Emie Benjamin, Rick Hurd, James Monks, Doug Shapiro, and Anne Machung for their comments on an earlier draft. 
A NLRB ruling in 200 r that permitted collective bargaining for teaching assistants at New York University (NYU), led the university in the following year to become the first private one to sign a contract with a union representing teaching assistants. Building on this ruling, graduate assistant organizing campaigns are underway at a number of prestigious private universities. In the third section we address why graduate assistants are increasingly interested in organizing and then present evidence on the effects of graduate student unions on a number of economic variables.

\section{Faculty Unions}

Statutes governing bargaining for federal and state government employees, NLRB decisions governing private higher educational institutions, and the Supreme Court decision in the Yeshiva case have heavily influenced the growth of collective bargaining for faculty in the United States. ${ }^{1}$ President John F. Kennedy's 1962 executive order, which permitted federal government employees limited bargaining rights, led to the signing of the first faculty contract at the U.S. Merchant Marine Academy in 1968.

State governments swiftly followed the executive order and established their own laws governing collective bargaining for public employees in their states. By 1972, thirty-seven states had passed legislation permitting their employees to bargain collectively, although many of them did not cover faculty. The first major faculty contract at a public higher education institution was at the City University of New York in 1969. A 1979 act in California giving collective bargaining rights to faculty and other employees of its four-year colleges led in 1982 to the organization of the eighteen-thousand-faculty-member California State University system.

Collective bargaining for faculty in private higher education took hold in the early 1970s when the NLRB ruled in a case involving Cornell University that nonprofit educational institutions could be required to bargain with theit employees. While this case did not apply directly to faculty, the NLRB ruled in another case involving a branch campus of Long Island University that faculty were not necessarily supervisors. This latter ruling was upheld in another NLRB case involving Fordham University. However, the U.S Supreme Court effectively put the brakes on private-sector faculty unionization efforts in 1980 , when in the Yeshiva case it ruled that faculty were managers and thus 
were ineligible to bargain collectively with their universities (NLRB v. Yesbiva University 944 U.S. 672 [1980]). Indeed, during the decade that followed, a number of institutions, including Boston University and Fairleigh Dickinson University, successfully sought to have previously approved faculty bargaining units decertified.

As a result, faculty unionization in U.S. higher education has become primarily a public-sector phenomenon. In the mid-r99os, about $3^{8}$ percent of full-time faculty in public higher educational institutions were covered by collective bargaining agreements, while only about 6 percent in private higher educational institutions were covered. ${ }^{2}$ Collective bargaining coverage for faculty also varied widely across Carnegie categories of colleges and universities (Carnegie Foundation for the Advancement of Teaching 1994). While over 40 percent of fulltime two-year-college faculty were covered by collective bargaining agreements, less than 3 percent of faculty at Liberal Arts I institutions were similarly covered. Lest the reader think that faculty unionization is strictly a two-year-college phenomenon, the proportions of full-time faculty members covered at Carnegie Research, Doctorate, and Comprehensive institutions were over 20 percent at this time.

The number of individuals covered by collective bargaining agreements relating to faculty at public two-year colleges in 1996 exceeded the total number of full-time faculty employed at these institutions that year, at least partially because these bargaining units often include many employees who are not faculty members. While some part-time faculty members are included in these units, nationwide less than 20 percent of part-time faculty are covered by collective bargaining contracts.

There has been a tendency in many academic institutions to increasingly rely on part-time faculty as a way of reducing costs. Between 1987 and 1998 , the proportion of adjunct and other faculty employed parttime in the United States rose from 33 to 42 percent, with most of the growth occurring during the first half of the period (Wilson $2001, \mathrm{Ar}_{7}$ ). It is only natural that the low pay and lack of benefits that many of these positions offer would serve as a stimulus for organization of the faculty members that hold them. However, while part-time faculty may have incentives to become unionized, they are difficult to organize for a number of reasons, including that many have other full-time jobs, public-sector part-time faculty are often excluded from full-time units, in some states (e.g., Ohio) part-time employee bargaining units are illegal in the public sector, and part-time faculty have high turnover rates. Having said this, in July 2002 , the United Automobile Workers (UAW) won the right to represent over four thousand part-time faculty 
members at NYU, making it the first adjunct-only faculty union at a major private university and one of the largest adjunct-only faculty unions in the nation (Smallwood 2002c).

Numerous studies have evaluated the impact of collective bargaining coverage on faculty members' salaries relative to faculty salaries at academic institutions where they are not covered by collective bargaining agreements. The result of these studies suggest that at best, faculty unions increase their members' average salaries by a very small percentage, and some found that faculty unions have had no effect. ${ }^{3}$ These findings should not be a surprise, for the following reasons: most faculty members covered by union contracts are employed in public higher education instimtions, most organized faculty in public higher education lack the legal right to strike, and the two major sources of revenue that finance faculty salaries-cuition and state appropriations-are typically controlled by the legislature and the governor, not by the trustees of the state institutions. With little bargaining power and very few monopoly rents to extract, one should expect unions to have a very small impact on faculty salaries. Indeed, faculty at many of the most prestigious public research universities, who have the most individual bargaining power (in terms of their ability to threaten to leave the institution if their salaries and other conditions of employment are not deemed adequate to them), have systematically chosen not to be represented by unions.

Some observers have feared that faculty unions would press for across-the-board raises in pay rather than merit increases, thus reducing the financial incentives that faculty have to be productive. However, a careful study of faculty contracts in higher education found that more often than not, they contained explicit provisions for merit increases (Rhoades 1998). Often, these contracts required that faculty groups be involved in the determination of which of their colleagues deserved merit increases, but this requirement is not in conflict with what proponents of a strong faculty role in governance should want.

Researchers have also attempted to ascertain the effect of faculty unions on a variety of other outcomes, including research productivity, job satisfaction, turnover behavior, salary differentials across fields, and the probability of obtaining tenure. ${ }^{4}$ In the main, these studies have been cross section in nature and have not controlled for the possibility that whether an institution's faculty members are covered by a collective bargaining agreement is not a random event. For example, if collective bargaining is more likely to be established in institutions where faculty are poorly treated by the administration and have low salaries 
and high turnover rates, it is possible that even if collective bargaining leads to an improvement in faculty salaries, one might still observe a negative relationship between collective bargaining coverage and faculty salaries. However, in this example the direction of causation would run from poor salaries to faculty collective bargaining coverage, not vice versa. The empirical analysis we undertake in the next section attempts to correct for this problem. ${ }^{5}$

One question that has yet to be addressed by researchers is how faculty unions influence the system of shared governance that is in place at many institutions. Shared governance by its nature is cooperative, while collective bargaining may be confrontational. ${ }^{\circ}$ A hypothesis, generated by one of us after participating for many years in faculty senate meetings at an institution without faculty bargaining, is that collective bargaining may actually improve the system of shared governance with respect to economic issues, because it allows faculty participating in shared governance to focus on what is best for the institution as a whole, not solely on what is best for the faculty.

To see this, consider the position of a faculty member participating on a joint faculty-administrative committee during deliberations on the institution's financial plan for the next academic year. If the average faculty salary increase has to be resolved as part of this discussion, the faculty member may focus his attention heavily on increasing this component of the budget, and not worry as much as he should about the other aspects of the budget. On the other hand, if the faculty salary increase pool is determined through collective bargaining and is not part of the budget deliberation, the faculty member can focus all of his attentions on the other aspects of the budget and more carefully consider all of the trade-offs involved. We encourage researchers to investigate the hypothesis that the presence of a faculty union may actually improve the functioning of systems of shared governance, at least with respect to economic issues.

\section{Staff Unions}

In $200 \mathrm{I}$, a twenty-day sit-in at Harvard University brought the livingwage debate to the forefront of American consciousness. ${ }^{8}$ After a sixmonth study, the Harvard Committee on Employment and Contracting Policies, a nineteen-member committee of faculty, staff, administrators, and students that had been appointed by Harvard's president as a result of the discussions to end the sit-in, recommended giving raises to the 
university's lowest-paid employees and relying more on collective bargaining in the future to ensure that the wages paid by subcontractors did not undercut local union wage scales ("Harvard Panel Recommends Wage Parity: Raises Coming to Cambridge?" Chronicle of Higber Education, I I January 2002, A34). A three-day sit-in at the University of Connecticut that related to the living-wage issue also yielded a substantive victory for campus workers. The protesters there generated an almost two-dollar increase in wages, as well as substantial improvement in benefits for many of the university's workers ("Sit-ins over Staff Wages Have Different Outcomes at Harvard and U. Connecticut," Chronicle of Higher Education, 25 March, 2001, A4I).

The growth of living-wage movements on almost one hundred campuses reflects the large variation in the wages paid to college and university staff across the country (Van Der Werf 2001). There are many potential explanations for these salary differences, including differences in local cost of living and differences in the resources that the academic institutions have available to pay faculty and staff salaries. One other possible explanation is the influence of staff unions. There have been no studies, however, of the impact of collective bargaining on staff salaries in higher education.

This section of our chapter addresses this issue. After providing some background data on the number of blue-collar and white-collar employees covered by collective bargaining agreements at U.S. higher education institutions, we use data from a $1997^{-1998}$ study on the costs of staffing in higher education conducted by the Association of Higher Education Facilities Officers (APPA) and other sources to estimate models that explain the variation across academic institutions in salaries for a number of narrowly defined blue-collar and white-collar occupational groups that are employed by the academic institutions' facilities divisions. ${ }^{9}$ Of primary interest to us is the extent to which the salaries of academic staff covered by collective bargaining agreements exceed the salaries of otherwise comparable academic staff that are not covered by such agreements.

Table 8.I presents data on the employment levels of blue-collar and white-collar staff members employed in U.S. higher education in the mid-I99os, as well as the percentage of each group that was covered by a collective bargaining agreement. The percentage of blue-collar employees represented by staff unions, $4^{2} .8$ percent, is much larger than the percentage of white-collar employees represented by staff unions, 23.4 percent. Because there are many more white-collar employees, in 
Table 8.I. Collective Bargaining Coverage of College and University Staff in 1994

\begin{tabular}{lccc}
\hline & Total Employees & $\begin{array}{c}\text { Estimated Employees } \\
\text { in Bargaining Units }\end{array}$ & $\begin{array}{c}\text { Percentage } \\
\text { Represented }\end{array}$ \\
\hline White collar & $1,070,142$ & 250,573 & 23.4 \\
Blue collar & 306,335 & 131,232 & 42.8 \\
TotaL & $1,376,477$ & 381,805 & 27.7 \\
\hline
\end{tabular}

Sources: National Center for Education Statistics 1994, 228-229 (tonal employees); National Center for the Sudy of Collecoive Bargaining in Higher Education and the Professions 1995 (employees in bargaining units).

Table 8. 2. Distribution of Academic Institutions by Camegie Category and Control in the APPA Sample

\begin{tabular}{lccc}
\hline Carnegie & \multicolumn{3}{c}{ Funding } \\
\cline { 2 - 4 } Category & Private & Public & Total \\
\hline Associate & 1 & 13 & 14 \\
Baccalaureate & 23 & 3 & 26 \\
Doctoral & 4 & 16 & 20 \\
Masters & 12 & 42 & 54 \\
Research & 7 & 42 & 49 \\
Total & 47 & 116 & 163 \\
\hline
\end{tabular}

the aggregate about 27.7 percent of staff at U.S. colleges and universities were covered by union contracts in the mid-r 990 s.

The salary and collective bargaining coverage data used in our study come from the APPA's 1997-1998 Comparative Costs and Staffing Report for Educational Faculties Association of Higher Education Facilities Officers $1999 .{ }^{10}$ This data set provided information on salary levels and collective bargaining coverage for forty-seven narrowly defined occupations at 193 U.S. and Canadian colleges, universities, and elementary and secondary schools. We restricted our attention to U.S. higher education instimations that could be classified as Research, Doctoral, Masters, Baccalaureate, or Associate (two-year) institutions (Carnegie Foundation for the Advancement of Teaching 1994) ${ }^{11}$ The sample that we used consisted of 163 institutions. Table 8.2 presents the breakdown of the institutions in our sample by Carnegie classification and by form of control. Public institutions constitute the majority of the institutions in each Carnegie category in our sample, except for the Baccalaureate category. 
Table 8.3. Mean Occupational Salaries in 1997-1998 for Employees Covered by Collective Bargaining Agreenents and Not Covered by Collective Bargaining Agreements in the APPA Sample

\begin{tabular}{lcc}
\hline Occupation & Mean Salary without Union & Mean Salary with Union (Ratio) \\
\hline Administrative secretary & 21,953 & $26,978(1.23)$ \\
Custodian & 16,993 & $22,850(1.34)$ \\
Groundskeeper & 18,838 & $26,138(1.39)$ \\
Carpenter & 26,206 & $35,962(1.37)$ \\
Electrician & 27,701 & $38,629(1.39)$ \\
Locksmith & 27,243 & $33,463(1.23)$ \\
Heating and cooling & 26,576 & $37,600(1.41)$ \\
Painter & 24,468 & $34,645(1.42)$ \\
Plumber & 26,852 & $37,575(1.40)$ \\
\hline
\end{tabular}

Source: Authors' computations from the APPA data (Association of Higher Education Facilities Officers I999). Only institutions that reported union coverage for an occupation and a salary figure for an occupation are included.

We restrict our attention to the nine occupations for which at least I 5 institutions in the sample reported both an occupational salary level and whether the employees in the occupation were covered by a collective bargaining agreement. Table 8.3 compares the mean annual salaries of unionized and nonunionized employees for each occupation, and provides the ratio of the mean salary for employees covered by union contracts to that for employees not covered by a union contract. The vast majority of these occupations are blue-collar occupations in the building trades.

In each occupation, employees covered by a union contract earned considerably more than employees not covered by a contract, with the raw differentials in the mean salaries varying across occupations from 23 to 42 percent. The differentials were largest in the skilled trades. Salaries for custodial workers, the group of employees that have been the focus of the living-wage debate on many campuses, were the lowest in the group, and the unionized custodial workers in the sample earned about 35 percent more on average than custodial workers not covered by a collective bargaining agreement.

The estimated differences in the salaries reported in Table 8.3 are raw differences that do not control for characteristics of the institutions or the areas in which the institutions are located, which might be expected to influence staff salaries independent of unionization. For example, if academic institutions whose employees were organized also had greater financial resources, or were located in higher-cost-of-living areas, than 
institutions whose employees were not organized, one would expect to observe the former paying higher salaries than the latter, even if unionization per se had no effect on the salaries of staff at academic institutions. To estimate whether staff unions do influence salaries, it is necessary to control for the other characteristics of the institutions that might influence salaries.

To accomplish this, we estimated staff salary equations, by occupation, in which the logarithm of the annual salary paid to a staff member in an occupation at the academic institution is specified to a function of a categorical variable indicating whether the particular occupation is unionized at the institution, a vector of categorical variables indicating the Carnegie classification of the institution, a vector of other variables that vary across institutions and are expected to influence staff salaries, and a random error term. Because the dependent variable is the logarithm of salaries, the interpretation of the estimate of the coefficient of the union variable is that it is the estimated percentage by which the salaries of staff in institutions with collective bargaining for the occupation exceed the salaries of staff at institutions without collective bargaining for the occupation, after controlling for the other factors expected to influence salaries.

We included in the set of other variables expected to influence staff salaries a number of variables that influence the resources that the academic institutions have at their command out of which to pay the salaries of staff. These include the logarithm of the institution's endowment per student, the logarithm of its average undergraduate tuition, and for public institutions the logarithm of its state and local government appropriation per student. ${ }^{12}$ In our basic specification, we also included the logarithm of the average salary that the institution pays its full professors, under the assumption that this probably represents the best single measure of the financial capacity of the institution. Also included in this vector, to control for differences in cost of living or wage levels across geographic areas, is the logarithm of the mean salary of custodians in the city in which the academic institution is located. When an institution was not located in a city for which we had mean custodian salary data, the mean custodian wage in the state was substituted. Finally, included in this vector is the logarithm of the average math and verbal SAT seventy-fifth-percentile score for entering frestimen at the institution. This variable, as well as the Carnegie category variables, was included to see if the "selectivity" of an academic institution, or its institutional type, influences the salary of its staff, once we have controlled for its financial resources. 
Row A of Table 8.4 presents the estimated coefficients of the collective bargaining coverage variable from our basic model. For six of the nine occupations, union coverage is associated, other factors held constant, with higher salaries, with the estimated differentials being in the range of 10 to 17 percent. The differentials are the largest for several of the occupations that historically have been heavily unionized nationwide in the building trades. Relevant to the living-wage debate, we observe that unionized custodians appear to earn about so percent more than nonunionized custodians at academic institutions, other factors held constant.

The remaining rows of Table 8.4 summarize the results of the additional econometric modeling we conducted to investigate the sensitivity of the estimated union coefficient to the variables included in the analyses and to the econometric methods we utilized. A key explanatory variable included in the estimating equation that yielded the results in row $\mathrm{A}$ was the logarithm of the average salary of full professors at the institution. One can easily argue that this variable should be treated as endogenous and that including it in the model may bias the estimated union coefficient. To see if the inclusion of the full-professor-salary variable mattered, we reestimated our equation excluding this variable from the analyses. The estimated union coefficients from this model specification are found in row B of Table 8.4. The exclusion of the fullprofessor-salary variable from the right side of the equation leads to slightly higher estimated union-nonunion differentials, with the statistically significant coefficients now ranging from 13 to 2 I percent.

The estimates presented in rows $A$ and $B$ of Table 8.4 treat each occupational equation as independent. They ignore the fact that there may be some omitted institutional-level variables that influence the salaries of staff commonly in all occupations. For example, the union-nonunion wage advantage for an occupation at an institution may depend on the fraction of the other staff occupations at an institution that are covered by collective bargaining agreements. Hence the wages for any given staff occupation at an academic institution may depend on the unionization of all staff occupations at the institution.

We attempted to reestimate the models underlying the collectivebargaining-coverage-variablem coefficients reported in row $\mathrm{A}$, adding as an additional explanatory variable the fraction of all nine occupations that were covered by collective bargaining agreements. ${ }^{13}$ Unfortunately, when one of the nine occupations was covered by a contract, the vast majority of the other occupations also were covered by a contract. Hence the coverage-by-union-contract variable for an occupation was 
Table 8.4. Logarithm of $1997-1998$ Occupational Salary Equations: Coefficients of Union Variables Sensitivity Analyses (Absolute Value of $t$-Statistics in Parentheses)

\begin{tabular}{lccccccccc}
\hline & $\begin{array}{c}\text { Administrative } \\
\text { Secretary }\end{array}$ & Custodian & Groundskeeper & Carpenter & Electrician & Locksmith & $\begin{array}{c}\text { Heating } \\
\text { and Cooling }\end{array}$ & Painter & Plumber \\
\hline A & $0.024(0.6)$ & $0.101(2.7)$ & $0.007(0.2)$ & $0.107(2.3)$ & $0.122(2.6)$ & $0.071(1.5)$ & $0.167(3.1)$ & $0.138(3.0)$ & $0.135(2.7)$ \\
B & $0.044(0.9)$ & $0.137(2.8)$ & $0.081(1.1)$ & $0.155(2.0)$ & $0.171(2.2)$ & $0.129(1.9)$ & $0.187(2.5)$ & $0.189(2.5)$ & $0.208(2.7)$ \\
C & $0.020(0.5)$ & $0.072(2.2)$ & $0.020(0.3)$ & $0.099(1.6)$ & $0.130(2.0)$ & $0.069(1.3)$ & $0.139(2.3)$ & $0.135(2.3)$ & $0.158(2.5)$ \\
D & $-0.013(0.3)$ & $0.030(0.7)$ & $-0.067(1.3)$ & $0.084(1.6)$ & $0.116(2.2)$ & $0.032(0.6)$ & $0.128(2.3)$ & $0.125(2.4)$ & $0.113(2.2)$ \\
\hline
\end{tabular}

Note: Row A shows ordinary least squares (OLS) coefficients of the union variable from the basic model; $B$ shows OLS coefficients of the union variable from model that excludes the logarithın of average faculty salary; $\mathrm{C}$, seemingly unrelated regression estimates of the union coefficients from the basic model for the sample of institutions that report data for all 9 occupations; and D, selectivity bias corrected estimates of the basic model. 
very highly correlated with the fraction of the nine occupations at the institution that were covered by union contracts. The high degree of collinearity prevented us from estimating such a model.

A second way to get at this issue is simply to treat the nine occupational salary equations as a single system and to allow the error terms to be correlated across equations. Estimating this system using the method of seemingly unrelated regressions will increase the efficiency of our estimates; however, as long as none of the other statistical assumptions is violated, the estimates reported in rows $A$ and $B$ of Table 8.4 will remain unbiased. ${ }^{14}$

The method of seemingly unrelated regressions will increase the efficiency of the estimated coefficients only if the identical explanatory variables do not appear in each equation. In our system, the only explanatory variable that varies across occupations is whether employees in an occupation are covered by a collective bargaining agreement at an institution. We have already indicated that the fraction of occupations organized at an institution is highly correlated with whether any one of the occupations is organized across institutions. Given this fact, it is not surprising that the estimated union coefficients that we obtained when we reestimated the model by seemingly unrelated regressions (the estimates found in row $C$ of Table 8.4) prove to be very similar to the coefficients found in row $A$ of the table. Any differences are probably due to sampling error, since the seemingly unrelated regression model could only be estimated using data on the subset of institutions that reported occupational salary and unionization data for all nine occupations.

Finally, our estimates of the salary advantage that staff who work in unionized academic environments have over staff who work in nonunion academic environments treat staff coverage by a collective bargaining agreement as being exogenous. If, for example, the institutions in which we observe staff covered by a collective bargaining agreement were initially the institutions in which staff compensation was lowest, other factors held constant, our estimates will understate the extent to which academic staff unions have improved their members' compensation relative to the compensation of academic staff at institutions not covered by collective bargaining agreements.

In the absence of having a panel data set that would permit us to estimate how changes in staff salaries at academic institutions are related to changes in collective bargaining coverage, the best way to handle this problem is to use the sample selection bias correction method developed by Heckman (1979) and Lee (1978). To implement this method, 
we estimate a probit equation for union coverage in an occupation in which union coverage is assumed to be a function of the other rightside variables in our salary equations, as well as the proportion of private-sector employees in the state who are covered by collective bargaining agreements, the proportion of public-sector workers in the state who are covered by collective bargaining, and the interaction of each of these variables with a variable indicating whether the academic institution is public or private. ${ }^{15}$ These interaction terms permit the impact of each of the sector coverage variables on the institution's probability of having its staff covered by union contracts to vary with the public or private status of the institution.

The estimated union coefficients that we obtained when the sample selection bias correction method was used are found in row D of Table 8.4. In most cases these estimates prove to be very similar to the ordinary least squares (OLS) estimates reported in row A. The estimated union coefficients for carpenters, electricians, heating and cooling technicians, painters, and plumbers remain statistically significant, and each coefficient is close to its value in the OLS equations. The estimated union coefficients for secretaries, groundskeepers, and locksmiths are statistically insignificantly different from zero, as they were in the OLS estimation. While custodians' salaries appeared to be higher when they were covered by a collective bargaining contract in the OLS specification, the selectivity-corrected estimate of the effects of unions on custodians' salaries is close to zero.

In contemplating what our findings mean, the limitations of our analyses should be kept in mind. The sample of $I_{6} 6_{3}$ academic institutions used in our study is not necessarily representative of the population of over 3,000 two- and four-year colleges and universities in the United States. The nine occupations whose salaries we analyzed all relate to employees employed in the facilities division, and the effects that we estimated for them are not necessarily representative of the effects for staff unions that one might observe for a wider range of college and university employees working in other areas (e.g., housing and dining, athletics, academic support, student services, external relations).

Nonetheless our findings do suggest that collective bargaining coverage influences staff salaries in higher education, and they imply that a direct way to achieve better salaries for low-paid college and university employees is to encourage them to organize and bargain collectively. Unlike private college and university faculty members, who are effectively precluded from collective bargaining at many 
Table 8.5. Universities That Have Recognized Teaching Assistant Unions

\begin{tabular}{lll}
\hline $\begin{array}{l}\text { Public Universities } \\
\text { before } 1999\end{array}$ & $\begin{array}{l}\text { Public Universities, } \\
\text { r999 and After }\end{array}$ & Private Universities \\
\hline CUNY & $\begin{array}{l}\text { Mlinois (Urbana) } \\
\text { Massachusetts (Boston) }\end{array}$ & New York University (2001) \\
Florida & $\begin{array}{l}\text { Michigan State } \\
\text { Oregon State }\end{array}$ \\
Florida A\&M & Rhode Island \\
Iowa & Temple University \\
Kansas & UC Berkeley \\
Massachusetos (Amherst) & UC Davis \\
Massachusets (Loweil) & UC lrvine \\
Michigan & UCLA \\
Oregon & UC Riverside \\
Rutgers (New Brusswick) & UC San Diego \\
South Florida & UC Santa Barbara \\
SUNY Albany & UC Santa Cruz \\
SUNY Binghamton & Washington (Seattle) \\
SUNY Buffalo & \\
SUNY Stony Brook & \\
Wayne State & \\
Wisconsin (Madison) & \\
Wisconsin (Milwaukec) & \\
\hline
\end{tabular}

Source: "Unionization Activity of Teaching Assistants," Chronicle of Higber Education: Almanac, 200z-2003 and December 6, zo02.

institutions because of the Supreme Court's decision in the Yeshiva case, there is no such prohibition to prevent staff at these institutions from organizing.

\section{Collective Bargaining by Graduate Assistants}

The first graduate student union to be recognized as a collective bargaining agent was at the University of Wisconsin in 1969 . As noted in an earlier section, collective bargaining at public higher education institutions is governed by state laws, and as state agencies or state courts ruled on the applicability of these laws to graduate assistants, collective bargaining for graduate students gradually spread at public higher education institutions. By 1999, teaching assistants at eighteen public Research and Doctoral universities were covered by collective bargaining agreements (Table 8.5), and in some cases these agreements also covered research assistants at the same campuses. Since the start of 1999, fifteen additional major research and doctoral universities have recognized graduate student bargaining agents, including all the campuses of the University of California. 
Teaching assistants at Yale University have been trying to organize and bargain collectively since 1990. The push for collective bargaining for graduate students at private universities got a major boost in February $200 \mathrm{I}$, when the NLRB ruled that graduate assistants at NYU had the legal right to form a union (Smallwood 200I). NYU subsequently agreed to enter into collective bargaining with the union, and a contract settlement was reached in February 2002 (Smallwood 2002a). Organization drives subsequently began at many other private universities, including Brown, Columbia, Cornell, Tufts, and Pennsylvania; a ruling by the NLRB that Brown assistants had the right to form a union has been appealed by the university. In fall 2002, Cornell became the first private university at which teaching assistants voted against forming a union.

The formation of graduate student unions is a bit of an anomaly to economists and collective bargaining scholars. The literature on unions suggests that they are most likely to arise in situations in which workers have long-term attachment to firms. Graduate students do not have permanent employment relationships with the universities at which they study, so why have they increasingly become interested in unionizing?

The University of Wisconsin was a hotbed of student activism in the late 1960 shen the first graduate student union was formed, and undoubtedly its formation was heavily influenced by this activism. The late 1960 also represented a booming time in the academic market for new Ph.D.s, with the time needed to earn a doctorate averaging five to six years in many fields and a widespread availability of good academic positions. However, since then things have changed. As Table 8.6 indicates, across all disciplines, the median total number of years enrolled between the granting of baccalaureate and doctoral degrees increased by 1.5 years between 1970 and 2000 . Focusing on the increase in the median times across all fields obscures the wide differences in the changes that occurred in many fields. In particular, while median time to earning a degree went up by less than two years in virtually all of the science and engineering fields, it went up by almost three years in the humanities. Humanities, and to some extent social science, graduate students found themselves spending more hours per week as teaching assistants, and service as a teaching assistant slows the time it takes to earn a degree (Ehrenberg and Mavros 1995).

In addition, the fraction of new $P h . D . s$ finding employment, let alone employment in tenure-track academic jobs, by the time they received their degrees declined substantially. For example, less than 59 percent 
Table 8.6. Median Number of Years Errolled between Baccalaureate and Doctorate Degrees

\begin{tabular}{lcc}
\hline Academic Discipline & 1970 & 2000 \\
\hline Engineering & 5.2 & 6.8 \\
Physical sciences & 5.3 & 6.5 \\
Geological sciences & 5.8 & 7.8 \\
Math and cotmputer science & 5.2 & 7.1 \\
Life sciences & 5.3 & 7.0 \\
Psychology & 5.3 & 7.2 \\
Social sciences & 5.8 & 8.1 \\
Humanities & 6.0 & 8.8 \\
Education & 6.3 & 8.3 \\
Total & 6.0 & 7.5 \\
\hline
\end{tabular}

Source: Authors' calculations from data found at WebCASPAR (hitp://caspar.nsf.gov).

of new Ph.D.s in the humanities reported having definite commitments of employment or plans for future study at the time they received their Ph.D., in 1998 (Sanderson et al. 1999). In some fields, such as the life sciences, at least one and often multiple postdoctoral fellow positions, frequently at relatively low salaries and without benefits, became the rule, rather than the exception, before young scholars had a shot at receiving a tenure-track position (National Research Council 1998). In sum, an increase in the time it takes to earn a degree and smaller and more distant payoffs at the end of the graduate school rainbow made highly educated graduate students a ripe target for unionization efforts.

The time it takes to earn a doctoral degree, the nature of support patterns while in graduate school, the relationships of graduate students to faculty, and job opportunities after receipt of the Ph.D. vary widely across fields. Degree times are shortest in the sciences and engineering fields, where many graduate students work closely with faculty as research assistants on sponsored research projects, develop research skills from this work, choose related dissertation topics, and then have good employment opportunities in the nonacademic as well as academic sectors. In addition, scientists' external research funding often permits them to supplement the size of the minimum graduate student stipend specified by their universities; they have external resources to pay what is needed to attract first-rate talent. As a result, many graduate students in the physical sciences and engineering are quite happy with their graduate school experiences.

In contrast, in the humanities there is less involvement of faculty and graduate students on joint research, a greater proportion of graduate 
students are funded via teaching assistantships, writing a dissertation takes considerably longer, and there are only limited nonacademic employment opportunities after receipt of the degree. Faculty members in the humanities only rarely have funds to supplement university teaching or fellowship stipends. Is it any wonder, then, that the push for graduate student unionization is often led by graduate students in the humanities and that often the unionization effort seeks to limit the bargaining unit to assistants (primarily teaching assistants) who are supported by the university rather than include those supported by external funds? ${ }^{16}$

Most universities that have been faced with a graduate student unionization campaign have vigorously opposed it. Public universities that have had collective bargaining relationships with their faculty for many years (e.g., the University of California and State University of New York systems) or collective bargaining relationships with their staff (e.g., the University of Illinois at Urbana), and have not seen these relationships lead to the demise of the university, still vigorously oppose such organizing campaigns. So too do many private universities: a large number of presidents of major private research unjversities testified before the NLRB, as well as did leaders of higher education organizations such as the Association of American Universities, the American Council on Education, and the Council on Graduate Schools, in opposition to the bid of the NYU graduate student union to be allowed to bargain collectively (Lafer $200 \mathrm{r}$ ).

Why have these universities opposed graduate student unionization? For some it is clearly the principled belief that a system of shared governance in which the parties (students, faculty, administrators, and trustees) reach decisions through mutual discussions is preferred to a system of conflict. For some it is the worry that graduate student unions will try to get involved in decisions that are more properly left to the faculty and administration, such as the assignment of specific students to different responsibilities and faculty members. For some it is the concern that "one size does not fit all" and that graduate assistant contracts will not allow for the wide diversity of individual arrangements that currently exist across departments within each campus. For some it is the fear that graduate student unions will impose financial costs on universities that they do not want to bear and that these costs will force them to make cutbacks in other areas, or to increase tuition by more than they would prefer to do.

Some of these fears appear to be unfounded, at least for public universities. Public employees in many states, such as New York, are pro- 
hibited from striking. Absent the major weapon that a union has to try to impose its desired contract on management, economists predict that the likely impact of the unions on public employees' compensation packages will be small. Certainly the literature discussed in an earlier section suggests that faculty unions' effects on their members' salaries and benefits have been small.

To date there have been no studies of the effects of graduate student unions on economic variables, but a data exchange conducted by a set of major universities provides some suggestive information. Under the condition that we would not divulge the name of any individual institution, or even the name of the data exchange, and would not present the data for any individual institution, we have been granted access to data on the salaries, compensation, and costs of teaching and research assistants at a set of public universities for a number of recent years. We have grouped these universities into four groups. Group A consists of sixteen institutions that have never had a collective bargaining relationship with graduate assistants. The second and third groups consist of four institutions that had collective bargaining arrangements with their graduate assistants before 1995 (group B), and these four institutions plus two more that first began bargaining with graduate assistants in 1995 or 1996 (group B + C). The final group consists of seven insttutions that first began bargaining with their graduate assistants during the 1999-200 xeriod (group D). For simplicity, we restrict our attention to, teaching assistants in what follows, but the data for research assistants yields very similar results.

Table 8.7 shows the mean values, across institutions in each group, for a number of economic variables for five academic years, $1996-1997$ through 2000-2001. The first panel presents the average stipends that teaching assistants received from the institutions during the academic year. Comparing the institutions where bargaining never occurred (group A) to those whose graduate students were covered by collective bargaining agreements by the first year in our sample (groups B and $B+C$ ), we observe that the institutions without collective bargaining had slightly lower average stipends in 1996-1997, but by 2000-2001, their stipends averaged the highest among the three groups. Whether this reflects the inability of graduate student unions to win large salary increases for their members, differences in the tightness of budgets in states where institutions with graduate students who are organized are located and the tightness of budgets in states where institutions with graduate students who are not organized are located, or a concerted effort by nonunion schools to raise stipends to discourage graduate stu- 
Table 8.7. Comparison of Teaching Assistant (TA) Salaries, Costs, and Compensarion at Public Research Universities with and without TA Unions

\begin{tabular}{llllll}
\hline $\begin{array}{l}\text { Outcome/Group } \\
\text { (number in group) }\end{array}$ & $1996-1997$ & $1997-1998$ & $1998-1999$ & $1999-2000$ & $2000-2001$ \\
\hline
\end{tabular}

\begin{tabular}{lccccc}
\hline \multicolumn{2}{c}{ Average TA academic-year salary } & & & & \\
A (16) & 10,370 & 10,617 & 10,990 & 11,378 & 11,817 \\
B (4) & 10,401 & 10,670 & 10,537 & 10,724 & 11,223 \\
B + C (6) & 10,561 & 10,891 & 10,950 & 11,352 & 11,686 \\
D (7) & 12,347 & 12,616 & 12,833 & 13,161 & 13,630 \\
Average TA academic-year compensation & & & & \\
A & 9,739 & 9,931 & 10,250 & 10,688 & 11,150 \\
B & 8,953 & 9,107 & 10,009 & 10,141 & 10,649 \\
B + C & 8,999 & 9,269 & 9,892 & 10,271 & 10,653 \\
D & 10,679 & 10,964 & 11,429 & 11,483 & 12,751 \\
Average TA academic-year cost & & & & \\
A & 14,009 & 14,492 & 15,079 & 15,612 & 17,350 \\
B & 14,415 & 14,855 & 16,019 & 17,756 & 17,318 \\
B + C & 13,354 & 14,020 & 14,925 & 16,001 & 16,132 \\
D & 15,345 & 15,676 & 18,375 & 16,256 & 18,627 \\
Average TA summer salary & 2,904 & 2,970 & 4,012 & 4,347 & 3,625 \\
A & 2,608 & 2,695 & 4,608 & 5,059 & 4,865 \\
B & 2,683 & 2,767 & 4,319 & 4,624 & 4,576 \\
B + C & 4,182 & 4,752 & 4,607 & 4,788 & 4,785 \\
D & 0.19 & 0.23 & 0.22 & 0.22 & 0.22 \\
Average TA salary/average assistant professor salary & & 0.21 & 0.20 \\
A & 0.20 & 0.22 & 0.21 & 0.21 \\
B & 0.20 & 0.23 & 0.23 & 0.22 & 0.22 \\
B + C & 0.21 & 0.26 & 0.24 & 0.24 & 0.24 \\
D & & & & & \\
\hline
\end{tabular}

Sontre: Authors' calculations from confidential data provided to the authors from a set of major research wiversities that participate in a data exchange program.

Note: A, public institutions without TA unions; B, public institutions with TA unions prior to 1995; B $+C$, group B plus public institutions with TA unions starting in 1995 or 1996; $D$, public insciturions with TA unions starting during the 1990-2001 period; "Compensation" indicates salary less the portion of tuition and fees that TAs must pay; "Cost," salary plus tuition and fees that university forgoes. The value of health insurance benefits provided to TAs is excluded from their salarjes. The share of health insurance costs paid for by a fee charged to students that is waived for TAs is inciuded in TA costs.

dents from organizing, cannot be determined from these data. What is of interest, though, is that the highest average stipends in each year occurred at institutions where graduate students organized for bargaining only during the later years of the period (group D). Many of these institutions are located in relatively high-cost-of-living areas, a point that we return to later.

The second panel of data shows the results when we deduct from the stipend paid at each institution the tuition and fees that teaching assis- 
tants who were in-state residents had to pay to the university. ${ }^{17}$ This is not a perfect measure of the teaching assistants' compensation because the value to the graduate students of any university-provided health insurance benefits would not be included in these numbers, and health insurance coverage has often been an issue that precipitated graduate student organizing efforts. A search of the Web sites of all the institutions in our sample suggested that by 2001-2002 (which is after our sample period) all but two of these institutions (one from group A and one from group B) provided at least partial funding for graduate student health insurance. Nonetheless, focusing on this compensation variable provides some evidence on how graduate student unions influence tuition remission decisions.

In 1996-1997, average teaching assistant compensation was higher at the nonunion institutions (A) than it was at the unionized institutions ( $B$ and $B+C$ ), which suggests, given the numbers in the previous panel, that required graduate assistant tuition payments were higher at the unionized institutions than they were at the nonunion ones. By 2000-200I, the differential had narrowed somewhat, suggesting that graduate assistants were able to win larger reductions in required tuition and fee payments at schools where graduate students bargained collectively. Again the average compensation of graduate assistants at the group $\mathrm{D}$ schools, the ones that organized near the end of the period, was the highest.

The third panel, displays what the costs of graduate assistants are to the institutions. These costs include the stipend and the portion of the students' tuition and fees that are not collected from them. Some of these costs are real costs, for example, the fees that graduate students would otherwise have to pay for mandatory student health insurance coverage. Some are opportunity costs, for example, the forgone tuition revenue that the university does not collect. Omitted from these costs are any university subsidies for benefits, such as health insurance, that the university makes for all graduate students, regardless of whether they are graduate assistants.

Viewed from this perspective, the average teaching assistant costs for the nonunion schools (group A) rose relative to those for the schools where graduate students were organized during the entire period (groups $\mathrm{B}$ and $\mathrm{B}+\mathrm{C}$ ), as well as relative to the costs at institutions where graduate students were organized only at the end of the period (group D). These comparisons do not support the view that graduate assistant unions increased universities' academic-year costs for graduate students during the period, although we caution that they may be driven by 
differential rates of tuition increases at the different sets of institutions during the period.

The next panel in the table provides information on the average stipends paid to graduate students for teaching assistant responsibilities during the summer. The average summer salaries at the nonunion schools started a few hundred dollars above those at the schools where graduate students were unionized throughout the period, but wound up substantially below them by the end of the period. Hence one economic effect of graduate student unions may be to win better stipends for summer work.

Interestingly, the stipends for summer teaching were highest throughout the period at the institutions where graduate students became unionized only at the end of the period. As noted earlier, many of the universities in this category are located in high-cost-of-living areas (see Table 8.5), and it is important to control for cost-of-living differences across areas before drawing any definitive conclusions from the comparisons presented so far.

There are several ways to control for cost-of-living differences. One can use variations in the cost of rental housing across areas to proxy for differences in the cost of living; such data can be obtained from the published Census of Population volumes, available from the government every ten years. One can use estimates of the costs of living in different areas prepared by commercial firms that advise corporations about how much to alter their executives' compensation when one relocates them. ${ }^{18} \mathrm{Or}$, one can simply say that what is relevant is how much teaching assistants are making relative to young tenure-track faculty, namely, full-time assistant professors. ${ }^{19}$ Using all three measures yields similar findings, and we report only the comparisons that adjust for assistant professor salaries here.

The final panel of Table 8.7 presents the latter set of data. We find little support from these comparisons for the proposition that graduate student unions increase the salaries of teaching assistants relative to the salaries of assistant professors. Initially, the ratio of average teaching assistant salary to average assistant professor salary is lowest at the institutions that never had collective bargaining for graduate assistants. However, over the period studied, it rises relative to the ratios at universities where graduate students bargained throughout the period. Similarly, it was highest throughout the period at the institutions that began bargaining with their graduate assistants only during the last sample year. That the ratio of graduate assistant to assistant professor salaries does not vary that much over time at these public institutions 
should not be too surprising-several of the graduate student contracts specify that the salary increase that their members are to receive will be equal in percentage terms to increases granted to the faculty. ${ }^{20}$

Taken together, the findings suggest that the impact of graduate assistant unions on economic outcomes does not appear to be very large and that concern about the issue of graduate student unions may be overstated. ${ }^{21}$ Indeed attracting and retaining top graduate students is an important objective of faculty at all research universities, and so the faculty is often supportive of increased stipends for graduate fellows and assistants. Concern about graduate assistant unions, for the most part, is an administrative, not a faculty concern.

Of course if the cost of graduate students increases too much, it is reasonable to expect that universities will seek alternative ways of meeting their staffing needs for undergraduate courses. If graduate student unions, or the bidding up of teaching assistant stipends in an effort to attract the best and brightest graduate students, lead to substantially increased costs for the students, it is reasonable to expect that ultimately universities will reduce the size of their $\mathrm{Ph}$.D. programs and make more use of lecturers and other non-tenure-track faculty to staff undergraduate courses. Another source of substitute labor is undergraduate teaching assistants. However, as the vote in favor of establishing a union for undergraduate resident hall assistants at the University of Massachusetts in March 2002 should suggest, once the line between financial aid and employment becomes blurred, academic institutions may well be subject to more organizing campaigns of undergraduate students ("Resident Assistants at UMass Vote to Unionize," Cbronicle of Higber Education, ${ }_{5}$ March 2002, A39). ${ }^{22}$ Institutions that offer undergraduate teaching assistantships for academic credit, rather than for compensation, might skirt this issue, but many faculty members challenge the legitimacy of giving academic credit for work as a teaching assistant.

Similarly, if graduate student unions bid up the costs of research assistants, and universities require faculty with external sources of funding to pay higher stipend levels and higher levels of tuition for graduate research assistants, faculty members may decide that they are better off employing more postdoctoral fellows and permanent lab staff and fewer graduate research assistants. So one impact of graduate student unions may be smaller Ph.D. programs.

One respected former university president is genuinely concerned that there may be a conflict between collegiality at universities and collective bargaining for graduate students (Duderstadt 2000, 94-95). ${ }^{23}$ In 
addition to worrying about graduate student unions getting involved with issues of class size and the assignment of teaching assistants, he worries that graduate student unions may lead to some breakdowns in the faculty-student mentorship relationship and ultimately a reduction in graduate program quality.

If this were true, one might expect to see things such as the time it takes to earn a degree and completion rates for Ph.D. students increasing at universities that have teaching assistant unions and, as a result, possibly a decline in the quality of students who apply to such programs. In contrast, if graduate student unions are seen as improving the atmosphere for students attending graduate school, such unions might be expected to lead to an improvement in the quality of the applicants and a general increase in program quality. To date, no tests of these hypotheses have been conducted.

\section{Conclusion}

The role of collective bargaining in higher education is likely to increase in the future. Most of the growth of higher education is occurring in the public sector, and it is in the public sector that both faculty and staff unions are the strongest (in terms of shares of individuals who are members) and where there are the fewest legal obstacles to the continued rise of collective bargaining. The decline of faculty salaries in the public sector relative to those in the private sector may also provide further impetus for future faculty organization issues, although the decline in public salaries has often been large in states where faculty unions already exist. Recent NLRB decisions seem to leave open the possibility that the Yesbiva decision may not apply to all private-sector faculty members and thus, possibilities may also exist for the growth of unions among faculty in private colleges and universities.

While extensive research has been conducted on the impact of faculty unions on salaries, benefits, and productivity, very little is actually known about how they influence faculty governance. One hypothesis, which has yet to be tested, is that by providing a means by which faculty may advocate for things (such as salaries) that are explicitly important to them, unionization allows faculty members involved in faculty governance to evaluate economic issues facing their institution more broadly from the perspective of the institution as a whole.

The growing living-wage movement on campuses, which has its roots in the notion that academic institutions have an obligation to treat their 
workers fairly, is also likely to provide a stimulus for efforts to increase union strength among staff at these institutions. Certainly the evidence that staff unions, unlike their faculty counterparts, seem able to improve their economic positions through collective bargaining should stimulate future growth in this area.

Finally, it will likely prove difficult for most major universities to resist the tide of graduate assistant organizing activity that is sweeping the nation. These unions provide a structure under which activist students can develop leadership skills, and the courts appear to be increasingly ruling in unions' favor. Our preliminary evidence suggesting that graduating student unions do not have a large impact on the economic well-being of their members is unlikely to sway die-hard adherents from the notion that graduate student unions will help to alter the imbalance between graduate students and their mentors that is often alleged to exist. 